\title{
WEALTH EFFECTS OF CONVERTIBLE BOND AND WARRANT- BOND OFFERINGS: A META ANALYSIS
}

\author{
Norhuda Abdul Rahim \\ Alan Goodacre \\ Chris Veld
}

2 August 2012

The European Journal of Finance, forthcoming

Keywords: convertible bonds, warrant-bond offerings, wealth effects, meta-analysis

Alan Goodacre is Professor of Accounting and Finance, Accounting and Finance Division, Stirling Mangement School, University of Stirling, United Kingdom, FK9 4LA (e-mail: alan.goodacre@stir.ac.uk). Corresponding author: Chris Veld is Professor of Finance, Accounting \& Finance, Business School, West Quadrangle, Main Building, Room G545, University of Glasgow, University Avenue, Glasgow G12 8QQ (e-mail: Chris.Veld@glasgow.ac.uk). Norhuda Abdul Rahim is a PhD-Student in the Accounting and Finance Division, Stirling Management School, University of Stirling, Stirling, United Kingdom, FK9 4LA (e-mail: n.a.abdulrahim@stir.ac.uk). The authors gratefully acknowledge helpful comments and suggestions by Artur Rodrigues, Peter Jones, Heather Tarbert, and participants at the Conference of the European Financial Management Association in Aarhus (June 2010) and the Scottish BAA in Glasgow (August 2010). Special thanks go to two anonymous referees and to the editor (Chris Adcock). 


\title{
WEALTH EFFECTS OF CONVERTIBLE BOND AND WARRANT-BOND \\ OFFERINGS: A META ANALYSIS
}

\begin{abstract}
:
We review the literature on wealth effects associated with the announcements of convertible bond and warrant-bond offerings. The findings of 35 event studies, which include 84 sub-samples and 6,310 announcements, are analysed using meta-analysis. We find a mean cumulative abnormal return of $-1.14 \%$ for convertibles compared with $-0.02 \%$ for warrant-bonds, the significant difference confirming a relative advantage for warrantbonds. Abnormal returns for hybrid securities issued in the United States are significantly more negative than those issued in other countries. In addition, issuing hybrid securities to refund debt does not seem to be favoured by investors. Finally, several factors identified as important by theory or in prior research are not significant within our cross-study models, suggesting that more evidence is needed to confirm whether they are robust.
\end{abstract}




\section{Introduction}

Companies can attract financing from different sources: they can issue equity in the form of shares of common stock or they can choose to attract debt. Another possibility is to attract a form of capital between equity and debt. The best-known alternatives in this area are issues of convertible bond and warrant-bond offerings. A convertible bond is a hybrid security that combines characteristics of bonds and equity. Convertible bondholders receive income from the bonds in the form of a coupon. In addition they have the right to convert the bonds into a specific number of common stocks within a specific period. Warrant-bond issues are a combination of straight bonds and separate warrants.

Convertible bonds have become more popular during the financial crisis of 2008-2009. Antoine de Guillenchmidt, Morgan Stanley's head of European equity-linked capital markets states in the Financial Times:

"A lot of investors are seeing the coupon as a way to maintain income if the dividend is cut. They are equity-type investors buying the bond as a way to get upside exposure with income." (Financial Times, $10^{\text {th }}$ May 2009)

According to statistics provided by the Financial Times, the United States has the largest market for convertible bonds with 6.1 billion US\$ issued by 17 companies between January and April 2009. In the United Kingdom, the new issues of convertible bonds are dominated by large firms such as Anglo American and Vedanta Resources.

Past empirical studies on warrant-bond and convertible bond issues find that convertible bond offerings are associated with negative abnormal returns. The verdict on warrant-bond issues in such studies is not completely clear: some studies find that warrant-bonds are also associated with negative abnormal returns, others conclude that warrant-bond offerings are a "penalty-free issuance of an equity-like security" (Billingsley, Lamy, and Smith 1990). In this context it is remarkable that we have not seen a resurgence of the market for warrant-bond issues. Another observation from previous empirical studies is that studies on the US market, from now on US studies, have systematically shown negative abnormal returns associated with convertible bond issues, while studies from other countries, such as Japan, Taiwan, and the Netherlands, sometimes show positive returns. If this is a consistent picture, it is remarkable that the resurgence of convertibles has taken place within the US. 
A number of papers have presented overviews of past literature on announcement effects associated with the issuance of securities. For example, Eckbo, Masulis, and Norli (2007) overview a large number of studies that calculate shareholder wealth effects associated with offerings of stocks, straight debt, and convertible debt. In a similar fashion, Loncarski, Ter Horst, and Veld (2006) present an overview table of studies on announcement effects associated with convertible bonds. The current study contributes to these previous studies by not only presenting an overview table, but by also using a specific type of metaanalysis, generally referred to as replication analysis, in which we conduct a regression analysis that summarizes a wide range of existing studies. This meta-analysis will show whether convertible bonds are associated with different abnormal returns than warrantbonds. It will also show whether there are any systematic country differences or differences associated with specific issuer characteristics.

We find 35 papers that report results on announcement effects of convertible bonds and/or warrant-bond issues. These papers include a total of 6,310 announcements within 84 subsample results. These sub-sample results are analysed using meta-analysis in line with previous studies such as Datta, Pinches, and Narayanan (1992) and Veld and VeldMerkoulova (2009).

We find a significantly negative mean cumulative abnormal return (CAR) of $-1.14 \%$ for announcements of convertibles compared with $-0.02 \%$ for warrant-bonds; the difference in means is statistically significant, confirming a relative advantage for warrant-bonds. In addition we find that US studies show significantly larger negative abnormal returns than studies outside the US, including those on market-oriented countries (such as the UK, Canada, and Australia); the difference is between $-1.1 \%$ and $-1.5 \%$, on average. Also, issuing hybrid securities to refund debt does not seem to be favoured by investors. Finally, several factors identified as important by theory or in prior research are not significant within our cross-study models, suggesting that more evidence is needed to confirm whether they are robust.

The remainder of this study is organized as follows: Section 2 briefly reviews the studies on the wealth effects that are associated with announcements of convertible bond and warrant-bond offerings. Section 3 includes a discussion of the factors that have the potential to explain these wealth effects. The model for the meta-analysis is included in 
Section 4. Section 5 describes the results, and the paper is concluded in Section 6 with a discussion of the implications of the results.

\section{Wealth effects of convertible bond and warrant-bond offerings}

An extensive set of event studies on announcements of convertible bonds and bonds issued together with warrants have been undertaken. All these studies document abnormal returns associated with the announcement. We review these studies by using a meta-analysis technique. We follow the approach of Datta, Pinches, and Narayanan (1992) and Veld and Veld-Merkoulova (2009) who use meta-analysis to study the wealth effects associated with the announcement of mergers and acquisitions and spin-offs respectively. In the metaanalysis in this paper the estimates of the abnormal returns associated with issuances of convertible bonds warrant-bonds are used as observations in a multi-factor experiment with the experimental factors corresponding to the factors hypothesized to influence the creation of wealth. Therefore the abnormal returns are the dependent variable. A multivariate regression analysis is used to assess the impact of each factor on the dependent variable.

We use library catalogues, Google, Google Scholar, and the Social Sciences Research Network (SSRN) to select all studies that present wealth effect results for announcements of hybrid debt. We include all studies that are publicly available on August 31, 2010. In some cases our own archives include older papers. In such case these papers are also included. Only papers in English are included. The papers that we analyze include studies in academic journals and working papers. The search results in 35 studies, of which 30 were published in academic journals and 5 working papers. The papers in academic journals were published from 1984 and the last paper was published in 2008. The dates on the non-published (or not yet accepted for publication) working papers are between 1990 and 2009. As is the case with most topics in finance, the majority of the papers are about the United States. However, there are also quite a few studies on countries outside the United States, such as studies for Western Europe, Japan, Canada, the Netherlands, and Taiwan. Table 1 summarizes the 35 papers and the wealth effects that they report.

[Please insert Table 1 here] 
The results of these studies vary. The studies on the announcement effects of convertible bonds in Japan reveal significantly positive market reactions in one study (Kang and Stulz 1996), but a significantly negative reaction in two studies (Mollemans 2002; Cheng, Visaltanachoti, and Kesayan 2005) as well as non-significant reactions in two studies (Kang, Kim, Park, and Stulz 1995; Christensen, Faria, Kwok, and Bremer 1996). The study on the Dutch market (De Roon and Veld 1998) also reveals non-significant positive market reactions associated with the announcement of convertible debt. All studies in the United States show significantly negative abnormal returns for the announcement of convertible debt. $^{1}$

Besides highlighting the mixed results of wealth effects associated with convertible bond issues from countries around the world, Table 1 also facilitates comparison between wealth effects of announcement of convertible bond and warrant-bond offerings. However, a nonstatistical comparison paints a mixed picture. Two US studies reveal significantly negative abnormal returns on announcements of warrant-bonds, but two show non-significant abnormal returns. For Japan, one study reports significantly positive abnormal returns for warrant-bond issues but two studies find negative (non-significant) abnormal returns. Finally, separate studies for the Netherlands and Germany highlight more positive response to announcements of warrant-bond issues than to convertible bond issues.

\section{Factors explaining wealth effects of convertible bond and warrant-bond offerings}

\subsection{Information asymmetry}

Myers and Majluf (1984) develop a model of security issuance that is based on asymmetric information between shareholders and managers. In their model managers have more information than shareholders. Therefore an equity issue is perceived as bad news according to this model, because the market will assume that managers try to maximize the wealth of their existing shareholders by trying to sell overpriced equity. This model predicts that an equity issue will be associated with a more negative abnormal return than a debt issue. The expected effect of an issue of hybrid debt, such as convertible bonds or warrant-bonds, will be between those of equity and debt. Empirical research for the United States confirms the predictions of the asymmetric information model. For example, an

1 In one study, Lewis, Rogalski, and Seward (2003), the significance level of the entire sample is not presented. 
overview paper of Eckbo, Masulis, and Norli (2007) finds that equity issues are associated with an average abnormal return of $-2.22 \%$. The average abnormal return is only $-0.24 \%$ for issues of straight debt, and $-1.82 \%$ for convertible bond issues. ${ }^{2}$

\subsection{The difference between convertible bonds and warrant-bonds}

Convertible bond issues and warrant-bond issues are both a combination of a straight bond and a warrant that allows the holder to purchase the underlying common stock. An important difference is the fact that a warrant in a warrant-bond issue can usually be detached from the bond either at the issuance date or very shortly thereafter. This detachability gives an advantage to warrant-bond buyers, since they can separately trade the warrant and the bonds. The detachability also gives the issuing company the option to set a different maturity for the warrant than for the bond. For convertible bond issues the maturity has to be the same because the bond disappears when the conversion right is exercised. This gives an advantage to the issuer of warrant-bond issues compared to convertible bond issues. On the other hand, a disadvantage of warrant-bond offers from the perspective of the issuer is that bondholders and warrant holders are not necessarily the same person or institution. Therefore, unlike convertibles, warrant-bonds cannot be forced into conversion by calling them, which is a disadvantage if firms want to obtain equity through the backdoor.

A number of studies investigate both convertible bond issues and warrant-bond issues and find different wealth effects in response to announcements to raise capital using these securities. However, the empirical evidence is not robust on this issue. Billingsley et al. (1990) document that the announcements of warrant-bond issues are associated with less negative abnormal returns than convertible debt. This finding is supported by De Roon and Veld (1998), Gebhardt, (2001), and Kang et al. (1995) in different markets. In contrast, Christensen et al. (1996), and Kang and Stulz (1996) find more negative abnormal returns for the announcements of warrant-bond issues than for convertible bond issues.

\footnotetext{
${ }^{2}$ All these numbers are for firm commitment offerings. Eckbo, Masulis, and Norli (2007) also calculate the average abnormal return for standby equity rights offerings to be $-1.33 \%$.
} 


\subsection{Equity- versus debt-likeness}

Firms can design a convertible bond by specifying security characteristics, such as coupon rate, maturity date, conversion ratio, and others. For example, convertible bonds that have a longer maturity and a lower coupon rate can be categorized as equity-like convertible bonds. Lewis, Rogalski, and Seward (2003) use the conversion probability as a guideline to sort convertible bonds into three groups. If the probability of conversion into equity is less than $40 \%$ the convertible bonds are considered as 'debt-like', between $40 \%$ and $60 \%$ as 'hedge-like', and greater than $60 \%$ as 'equity-like'. They find almost identical negative market reactions, of just over $-1 \%$, to announcements for the three groups. Suchard (2007) also finds similar (non-significant) negative returns for announcements of debt-like and equity-like convertibles in the Australian market. On the other hand, Loncarski, Ter Horst, and Veld (2008) find that equity-like convertible bonds are associated with a negative 3day abnormal return of $-3.7 \%$, which is significantly higher than the $-0.1 \%$ abnormal return for the announcement of debt-like convertibles. For the French market, Burlacu (2000) argues that equity-like convertible bonds have more negative market reactions associated with their announcements but the results appear less clear-cut.

\subsection{Differences in corporate governance systems}

Since our meta-analysis incorporates studies from around the world, it is necessary to take into account country specific characteristics. Moerland (1995) suggests two categories of corporate governance systems that may have an impact on economic events: marketoriented systems and network-oriented systems. Market-oriented systems (also called Anglo-Saxon systems) have well-developed financial markets, many firms are listed on the stock exchange, and they have active markets for corporate control. The United States, United Kingdom, Canada, and Australia are categorized as market-oriented systems. On the other hand, network-oriented systems typically have closely held corporations (e.g. having family ownership structure), group membership of corporations (e.g. having state ownership), high involvement of banks in financing and decision making, and close trading ties. Countries included in the network-oriented systems are Germanic countries (Germany, Switzerland, Austria, and the Netherlands), Latinic countries (Italy, Spain, France, and Belgium), and Japan. 
It is possible that differences in corporate governance systems may contribute to different results. De Roon and Veld (1998) argue that a difference in corporate governance is not responsible for differences in abnormal returns between Dutch and US convertible bond and warrant-bond offerings. Kang et al. (1995) find positive abnormal returns for Japan in response to announcements of warrant-bond issues. They suggest that this may reflect the different financial system during the study period, whereby equity-linked issues are guaranteed by a bank which conveys positive news to investors. In this meta-analysis, we have 22 market-oriented studies and 13 network-oriented studies. Our meta-analysis will investigate whether differences in corporate governance systems are responsible for differences in abnormal returns. ${ }^{3}$

A significant proportion (> 50\%) of studies of the announcement effects of convertibles and warrant-bonds are based on the United States. It is important, therefore, to consider whether non-US results might differ, so we split the market-oriented corporate governance variable between the US ${ }^{4}$ and other market-oriented countries by adopting US and non-US market-oriented dummy variables, with network-oriented studies as the (omitted) base variable.

\subsection{Rights offering}

Convertible bonds are sometimes issued in the form of a rights offering. Rights offerings are a puzzle in equity issues. In the United States most companies prefer firm-commitment offerings over rights offerings even though firm commitment offerings are associated with lower abnormal returns (see e.g. Eckbo and Masulis, 1992; Kothare, 1997). Unlike US firms, British firms prefer the use of open offers and placings for their seasoned equity offerings over the use of rights offers (Armitage, 2010). A placing is the UK equivalent of a firm commitment offering. Slovin, Sushka, and Lai (2000) define a placing as a form of public offering in which an underwriter purchases new securities offered by the issuing

\footnotetext{
${ }^{3}$ La Porta, Lopez-de-Silanes, Shleifer, and Vishny (2000) present an alternative classification based on investor protection. Table III of their paper groups countries into high and low protection. In their classification, the US and Japan are in the same category (high protection). Since the original paper of Kang and Stulz (1996) uses corporate governance differences to try to explain the difference in abnormal returns between the US and Japan we felt that it did not make sense to put both countries in the same category. For that reason we use the classification suggested by Moerland (1995).

${ }^{4}$ Almost all early studies were based on US data, leading to a strong association across sub-samples between 'early study' and 'US study' [chi-sq $=27.1 ; \mathrm{p}<0.1 \%$ ]. This high correlation means that it is not meaningful to incorporate an 'early study' variable to see if there is evidence of the wealth effect associated with hybrid debt issues changing over time.
} 
firm at the stated price. The underwriter then sells the shares to institutional investors and other outside shareholders without a commission. The preference for placings over rights issues is confirmed in a number of empirical studies that find higher abnormal returns for placings than for rights issues in both the UK and Australia. ${ }^{5}$

For convertible bonds, Abhyankar and Dunning (1999) find an abnormal return associated with placing announcements of $-1.51 \%$ compared with $-0.95 \%$ for rights issues (both significant at the $1 \%$ - level). For open offers they find an abnormal return of $-8.27 \%$ (but based on a very small sample of four announcements). These results are remarkable given that, for UK equity issues, rights issues are associated with more negative abnormal returns than placings. Market reactions to announcements of rights offerings of convertible bonds in other countries are: $-0.4 \%$ (not significant) (Australia: Suchard, 2007); $-0.65 \%$ (Germany: Gebhardt, 2001); and -0.77\% (United States: Eckbo, 1986).

\subsection{Stated reasons for offering}

There are various reasons why corporations need financing, including to finance capital expenditures, new investments, growth of the company, general funding, or to refinance debt. According to Myers and Majluf (1984) issuing securities for investment opportunities sends a negative signal to the market. In contrast, the sequential financing hypothesis of Mayers (1998) suggests that convertible bonds reduce the issuance costs and also present a solution for the free-cash flow problem. With forced conversion firms can use the funds to take-up positive net present value projects or to fund capital investment. With regard to issuance of securities to refund debt, Ross (1977) argues that a debt increase signals that the firm is confident about its future earnings potential. Vice versa, a debt refund signals bad news (see also Mikkelson and Partch, 1986).

Studies by Eckbo (1986) and Mikkelson and Partch (1986) reveal that issuing convertible debt for refunding existing debt, to finance capital expenditures, and general refunding is associated with significantly negative abnormal returns. Abhyankar and Dunning (1999) find a positive abnormal return of $1.08 \%$ (significant at the 5\%-level) to announcements of convertible bonds that are used to pay for capital expenditure but a negative abnormal return of $-2.9 \%$ (significant at the 10\%-level) for debt refinancing.

\footnotetext{
${ }^{5}$ See e.g. Slovin et al. (2000), Armitage and Snell (2001), and Barnes and Walker (2006) for the UK and Arsiraphonphisit (2008), and Balachandran, Faff, and Theobald (2008) for Australia.
} 


\subsection{Rating of convertible bonds}

Stein (1992, p. 17) suggests that 'the greater is the potential for costly distress (i.e., the lower the bond rating) the more credible is the convertible as a signal of optimism'. This statement implies that a firm with a lower rating bond, which uses a convertible bond as a method of financing, is optimistic enough that it will be able to force conversion and will eventually not be left with an additional debt burden. Therefore Stein (1992) argues that the issuance of a convertible bond should be considered as good news and should be treated with a less negative announcement effect compared to an equity issue of the same size by the same firm.

Empirical studies by Mikkelson and Partch (1986), Jen, Choi, and Lee (1997), and Kang and Stulz (1996) find results that are consistent with the theory of Stein (1992). However, Eckbo (1986) documents contradictory results in the sense that convertible bonds with high Moody's ratings (Aaa-Aa and A) have non-significantly negative abnormal returns while convertible bonds with a low rating (Baa-Caa) have significantly negative abnormal returns during the announcements of these securities. In order to test Stein's theory we compare abnormal returns between convertible bonds with different ratings in the metaanalysis.

\subsection{Size of the firm}

Some studies use firm size as a measure of asymmetric information, arguing that small firms tend to have higher asymmetric information compared to large firms. Larger firms such as listed firms have an obligation to release certain information to public, while small firms have a tendency and greater opportunity to keep information private. The greater the degree of information release by firms, the smaller the expected absolute level of market reaction to security issue announcements. Kang and Stulz (1996) report mean abnormal returns of $+2.7 \%$ and $+2.9 \%$ for convertible bond announcements of large and small Japanese firms, respectively, with the difference not being significant. Similarly De Roon and Veld (1998) found no significant difference between large and small firm abnormal returns in the Netherlands for convertibles or for warrant-bonds. However, Gebhardt 
(2001) reports a positive abnormal return (+0.57\%) for large German companies that announce issues of warrant-bonds, but this is significantly lower than for small companies $(+3.12 \%)$. All 3 studies adopt event windows of more than two days when analysing firm size effects so cannot be included within the two day event window meta-analysis here.

\subsection{Industrial versus non-industrial companies}

Smith (1986) notes that utilities tend to issue more external capital than industrial companies. For this reason, the stock price reaction associated with security issues by utilities can be expected to be less negative compared to those of industrial companies. Janjigian (1987) studies the stock price reactions of 234 industrial companies, 32 financial firms, 23 transportation firms, and 12 utilities in the United States that issue convertible bonds. He finds that utilities exhibit a (non-significant) abnormal return of $-0.87 \%$ as compared to $-1.71 \%$ for industrial firms (significant at the 1\%-level). Similarly, Suchard (2007) finds that convertible bond issues by Australian industrial firms are associated with more negative abnormal returns than resource firms (comprised of minerals and energy sectors). In line with Smith (1986), Janjigian (1987), and Suchard (2007), we expect that industrial companies will exhibit more negative abnormal returns than utilities and similar sectors. ${ }^{6}$

\subsection{Publication Bias}

We collect articles from various sources including working papers and articles in topranked finance journals. Therefore, there is a possibility that we are facing a publication bias. We include two dummy variables to investigate publication bias (after Veld and Veld-Merkoulova, 2009). The first variable identifies studies published in one of the journals included in the Social Sciences Citation Index (SSCI) journal list. The second identifies studies published in one of the Top-3 finance journals (The Journal of Finance, Journal of Financial Economics and Review of Financial Studies).

\footnotetext{
${ }^{6}$ Another type of non-typical companies is 'financials'. Most studies in our sample eliminate financial companies, because they have different considerations when choosing their capital structure compared to industrial companies and utilities.
} 


\section{Methods}

\subsection{Meta-analysis}

We use meta-analysis to review studies on wealth effects of the announcement of convertible bond and warrant-bond issues. Meta-analysis is an alternative to narrative literature review and can be defined as (Green and Hall, 1984, pp. 37-38):

'....the use of quantitative methods to summarize and analyze research literature......which treats the study as the unit of analysis and is entirely based on quantitatively expressed study attributes and outcomes'

One of the advantages of using meta-analysis is that we can derive statistically strong conclusions from the collected empirical evidence. In addition, meta-analysis provides more objective results compared to traditional literature reviews. Scholars also highlight advantages of meta-analysis include stressing gaps in the literature, offering new guidelines for research, and identifying ambiguous relationships among variables (Wolf, 1986). While theories may be valid within-sample when tested within the original studies, the evidence may not be sufficiently convincing in the between-sample tests employed in a meta-analysis. This would suggest the possibility that some prior results may be samplespecific and argues for study replication across different environments and time-periods.

\subsection{Model}

Wealth effects are typically measured using the 'event study' method that analyses stock price reactions associated with announcements of unpredictable events. Event study procedures include estimating abnormal returns using either mean adjusted returns, market adjusted returns, Capital Asset Pricing Model (CAPM) returns, matched or control portfolio returns, and market model returns. Basically, unpredictable events will lead to three possibilities: positive abnormal returns, negative abnormal returns, and neutral or zero abnormal returns. If the unpredictable event leads to a positive abnormal return, we can state that the event creates value to shareholders or increases shareholders wealth and if the unpredictable event leads to a negative abnormal return, we can state that the event destroys value for shareholders, or decreases shareholders wealth. 
In this paper we use a form of meta-analysis that is generally referred to as replication analysis. In this form of meta-analysis the abnormal returns from previous studies are used as observations in a multi-factor natural experiment, with the experimental factors corresponding to the factors hypothesized to influence wealth creation (Datta, Pinches, and Narayanan, 1992, p. 71). The dependent variable is the abnormal return, which is an estimate of the wealth created. Multiple regression analysis is used to assess the impact of each factor on the dependent variable. As is common in meta-analysis the factor levels are based on data available in previous studies. For example, we can identify studies on the United States (US studies) from those in other countries. In addition, we can use subsamples for which these studies present abnormal returns. However, we fully depend on the choices that previous studies have made. For example, some studies present separate results for equity-like, debt-like, and mixed-like convertible bonds. Unfortunately, not all studies use exactly the same definition for these variables. The relation between dependent and independent variables can be described as: ${ }^{7}$

$\mathrm{CAR}_{\mathrm{t}, \mathrm{s}}=\mathrm{f}\left(\mathrm{CB}_{\mathrm{s}}\right.$ vs. $\mathrm{WB}_{\mathrm{s}}$, Equity-like $\mathrm{s}_{\mathrm{s}}$, Mixed-like $\mathrm{s}_{\mathrm{s}}$, Non-US Market ${ }_{\mathrm{s}}$, United States $\mathrm{s}_{\mathrm{s}}$,

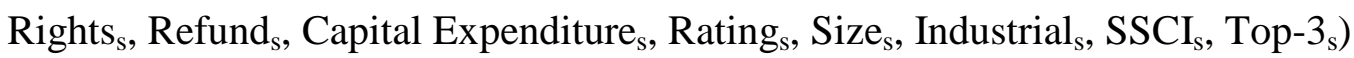

Where:

$\mathrm{CAR}_{\mathrm{t}, \mathrm{s}} \quad=$ short-run cumulative abnormal return in study s over $\mathrm{t}$ days;

$\mathrm{CB}_{\mathrm{s}}$ vs. $\mathrm{WB}_{\mathrm{s}} \quad=$ issue is $\mathrm{CB}$ convertible bond $(1=\mathrm{Yes}) ; 0=\mathrm{WB}$ (warrant-bond);

\section{Equity- versus debt-likeness}

Equity-like $_{\mathrm{s}} \quad=$ issue is defined in the original paper as equity-like $(1=$ Yes $)$;

Mixed-like $_{\mathrm{s}}=$ issue is defined in the original paper as mixed-like or is not identified

$$
(1=\text { Yes }){ }^{8}
$$

\footnotetext{
7 A problem with our analysis is that we treat the choice between CBs and WBs as exogenous. If unobservable factors determining the decision to issue convertibles versus warrant-bonds also influence stock price reactions to these offerings' announcements, then the dummy variable capturing CB versus WB will be biased. Ideally we would like to use a two-step Heckman (1979) procedure to verify whether our results are robust for controlling for endogeneity of the choice between hybrid instruments. Unfortunately, this procedure is not possible for us since we don't have access to the data used in the original individual analyses.

${ }^{8}$ The definition of equity-like, debt-like, and mixed-like is not the same in each paper. Burlacu (2000) uses the factor $\mathrm{N}\left(\mathrm{d}_{1}\right)$ (delta) from the Black-Scholes model and defines convertibles with a delta between 0 and 0.33 as debt-like, between 0.33 and 0.66 as mixed-like, and between 0.66 and 1 as equity-like. Lewis, Rogalski, and Seward (2003) us the factor $\mathrm{N}\left(\mathrm{d}_{2}\right)$ from the Black-Scholes model (probability of conversion) and define a bond as debt-like if the probability is less than $40 \%$, as mixed-like (called hedge-like in their paper) if the probability is between $40 \%$ and $60 \%$, and as equity-like if the probability is higher than $60 \%$. Suchard (2007) uses the same probability of conversion as Lewis et al. (2003), but defines convertibles with
} 
The omitted dummy here is Debt-like enabling direct comparison with Equity-like

\section{Differences in corporate governance systems}

Non-US Market $_{\mathrm{s}}$ $=$ market-oriented economy other than US (UK, Canada, and Australia) $(1=$ Yes $)$;

United States $_{\mathrm{s}} \quad=$ study on the United States $(1=$ Yes $)$;

The omitted dummy here is study on a network-oriented country

Rights $_{\mathrm{s}}$ $=$ rights offering $(1=$ Yes $) ; 0=$ any other issue mechanism

\section{Reasons for offering}

Refund $_{\mathrm{s}}$ = funds are used for refunding old debt $(1=$ Yes $)$;

Capital Expenditure $_{\mathrm{s}} \quad$ = funds are attracted for capital expenditure $(1=$ Yes $)$;

The omitted dummy here is any other reason for offering or unknown reason, including both non-disclosure by issuer or not investigated in original study

Rating (high) s $_{\mathrm{S}} \quad=$ high debt rating, ' $\mathrm{A}$ ' or higher bond rating (according to Moody's or Standard and Poor's rating) $(1=$ Yes $) ; 0=$ rated below ' $A$ ' or not investigated in the original study

Size (large) $)_{\mathrm{s}}$ $=$ large firm as defined in the original paper $(1=\mathrm{Yes}) ;{ }^{9} 0=$ not large or not investigated in the original study

Industrial $_{\mathrm{s}}$ $=$ industrial company $(1=$ Yes $) ; 0=$ non-industrial companies (e.g. financial, transportation, utilities)

$\mathrm{SSCI}_{\mathrm{S}}$ $=$ published in a journal that is included in the Social Sciences Citations Index (SSCI) list of $2008(1=$ Yes); $0=$ output in other journals and working papers

Top-3s $=$ study is published in one of the Top-3 finance journals, i.e. The Journal of Finance, Journal of Financial Economics, or Review of Financial Studies $(1=$ Yes $) ; 0=$ output in other journals and working papers

\footnotetext{
a probability less than 0.5 as debt-like and higher than 0.5 as equity-like. Loncarski, Ter Horst, and Veld (2008) use the delta and define convertibles with a delta lower than 0.5 as debt-like and higher than 0.5 as equity-like. Most studies do not distinguish between equity-like and debt-like and are therefore treated as 'mixed-like'.

${ }^{9}$ The papers that present separate results for large and small firms all divide the total sample in two equal parts: the largest half of the firms are labelled as large firms and the smallest half of the firms are classified as small firms. Kang and Stulz (1996) define firm size as the market value of equity. De Roon and Veld (1998) define firm size as the sum of the market value of equity and the book value of debt.
} 


\section{Results of the meta-analysis}

The 35 studies summarized in Table 1 provide the data for the meta-analysis. In our main models we use all sub-samples that report a mean CAR for a two-day event window (typically day -1 to day 0 , but depends on announcement day definition) around the hybrid security announcement. To achieve greater study coverage, and provide robustness checks, we also estimate models incorporating studies that report short-run mean CARs over event window periods other than two-days. While we use the closest period to two days, the inclusion of different periods within the dependent variable is a limitation of these models. ${ }^{10}$ Many of the 35 studies present separate subsamples involving analysis of at least one of the variables mentioned in Section 3, leading to 76 (two-day) and 84 (all) observations. $^{11}$

Table 2 reports separately the mean and median cumulative abnormal returns (CARs) for 74 sub-sample studies of announcements of convertible bond and 10 studies of warrantbonds. Overall, the studies include a total of 6,310 company announcements with 5,618 and 692 for convertibles and warrant-bonds, respectively.

\section{[Please Insert Table 2 here]}

For convertibles, the mean CAR across 74 observations is $-1.14 \%$ (significantly different from zero at the $1 \%$-level). While the range of CARs is quite large $(-8.27 \%$ to $+2.37 \%)$, the close proximity between mean and median suggests that outliers are not a major issue in the measure of central tendency. The mean CAR across 10 warrant-bond studies ranges between $-1.59 \%$ and $+1.41 \%$ with a non-significant overall mean of $-0.02 \%$. The difference between overall means for convertibles and warrant bonds is statistically significant (5\%-level); the distributional difference is confirmed (at the 5\%-level) using the non-parametric Wilcoxon rank-sum/Mann-Whitney test. In other words, there is univariate evidence confirming a more negative wealth impact of announcing the intention to issue

\footnotetext{
${ }^{10}$ In eight sub-samples the measures were over a 3 day event window $(-1,1)$, in two over just the one announcement day (0), and in one for a four day window $(-2,1)$.

${ }^{11}$ One very small $(n=4)$ sub-sample with CAR $=-8.27 \%$ was identified as an outlier during the CAR-based regression diagnostic tests, so is excluded from the CAR regressions; however, it is included in the t-statisticbased regressions.
} 
convertibles than warrant-bonds, consistent with the theoretical arguments in Section 3 above.

The multivariate regression results are shown in Table 3. The expected sign column in the table identifies the expected sign for the coefficients, based on the discussion in Section 3. Models 1 through 3 are based on mean CAR as the dependent variable. Models 4 to 6 report results for the same models, but with the $t$-statistics of the mean CARs as the dependent variable. The models provide reasonable explanatory power, with adjusted $\mathrm{R}^{2}$ ranging between $19 \%$ and 37\%, and averaging 29\% across the 6 models. Multicollinearity is a relatively minor issue with estimated variance inflation factors (VIFs) within the 1-3 range.

[Please Insert Table 3 here]

Model 1 is a simple OLS regression based on studies reporting 2 day event window mean CARs. In this model, four variables are statistically significant factors in determining reported wealth effects: CB vs. WB, United States, Refund, and SSCI. The coefficient on $\mathrm{CB}$ vs. WB suggests that announcements of convertibles suffer a larger negative wealth effect $(-0.67 \%)$ than warrant-bonds. This result is significant at the $5 \%$-level. The coefficient for US studies is significant at the 1\%-level and is also large in economic terms: the wealth effect of US hybrid securities is $1.11 \%$ lower than that of hybrid securities issues outside the US. The coefficient on Refund is significantly negative (at the 5\%-level). The result suggests that issuing hybrid securities to repay debt is not favoured by market participants;: the effect is $-1.62 \%$. Perhaps the market views the non-replacement of debt with further debt as an indication of the lack of confidence, or even desperation by managers of the issuing firm. Studies published in SSCI journals tend to have a positive wealth effect bias; perhaps more positive announcement effects are considered more interesting given the underlying expectation of a negative effect, leading to publication in relatively prestigious journals. ${ }^{12}$

\footnotetext{
${ }^{12}$ Interestingly, when we use publication in the Top 3 finance journals as an alternative proxy for publication bias we find (in models not reported in the Tables) no significant effects. This lack of significance seems to stem partly from a lower mean effect-size and partly from reduced power, reflecting smaller sample size for 'Top 3'.
} 
A large number of factors have non-significant coefficients including the equity-like or mixed-like characteristics of convertibles, bond rating, whether funds are used for capital expenditures, rights issues, and non-US market. ${ }^{13}$ These results suggest that the withinsample evidence from prior research on such issues does not appear to be robust when other factors are taken into account within our between-study analysis. Absent further, more robust, evidence we must assume that they do not have a major impact on announcement wealth effects. ${ }^{14}$

There are two issues in the above OLS-based analysis. First, different studies estimate CARs with different levels of precision, which suggests that the errors in the meta-analysis are likely to be heteroskedastic. This implies that different observations should be accorded different weights in the analysis, ideally based on the estimated standard errors within the relevant original study. Unfortunately, standard errors are not usually reported in the studies so we adopt a proxy weight based on sample size, consistent with several prior meta-analysis studies (e.g. Day 1999; and other references within Nelson and Kennedy 2009). In line with prior studies we use the square root of the sample size as weights within a Weighted Least Squares regression, and also employ Huber-White adjusted standard errors where necessary in the regressions.

The second issue with the results in Column (1) is that the individual observations used in the meta-analysis involve overlapping samples. For example, our study includes several papers using US data. These studies are likely to use the same hybrid debt announcements for at least part of their samples. Further, in several cases, the same data is used by the original authors to test different hypotheses (e.g. firm size, credit rating, etc.) and these are included as separate observations in our regression. Datta et al. $(1992,73)$ argue that this issue does not represent a problem in their study: "Although the population of acquisitions from which the studies have drawn their samples is finite, the sampling criteria are so different that observations are treated as being independent of one another. Similarly, while multiple observations from the same study have been used, they represent wealth estimates from samples unrelated to each other". These arguments are not entirely convincing, for

\footnotetext{
${ }^{13}$ Firm size effects cannot be investigated in the 2-day event window models as the three original studies investigating the effects use longer than 2-day windows in their analysis (see Section 3.8).

${ }^{14}$ However, this result needs careful interpretation as the comparator group (omitted dummy variable) in several comparisons includes studies that do not identify the specific characteristic under test (e.g. high credit rating). This means that the comparator group may actually include an unknown number of companies having the specific characteristic. If true, this would bias the tests against finding significant coefficients.
} 
our context at least, so we also include an adjustment for overlapping samples as a robustness check in Column (2) of Table 3. We follow Nelson and Kennedy (2009, 355) who argue that if a study has two sets of results counting in the meta-analysis (e.g. the same data is used for a size comparison and a rating comparison) the results for each set should be weighted by one half in a weighted least squares regression. Column (2) includes this analysis, but in addition we apply the same logic to 'countries', which is especially important for the US. We estimate the total number of unique observations (separately for CBs and WBs) based on tables of sample sizes per calendar year reported in various studies (taking the largest yearly sample reported). Comparing the total number of unique observations with the total number of overlapping observations provides a scaling down factor per country that is used for all potentially overlapping studies, scaled down again if multiple results from one study are used on the meta-analysis. ${ }^{15}$ The overall effect of this is only to include the 'evidence' from the unique observations. The results in Column (2) are very similar to those in Column (1). The same four variables are significant, but the exact sizes of the coefficients and the significance levels are slightly different.

In Column (3) we include all the studies that are represented in Column (1) and in addition we include studies that only present event period results for other than 2-day event windows. Therefore, the number of observations for Column (3) goes up to 83 (from 75 in the first two columns); we revert to simple OLS estimation as in Column (1). The incorporation of event studies that only report other than 2-day windows allows us to also study the variable for firm size. The results in Column (3) are virtually identical to those in Column (1) except that the significance levels are slightly higher. The coefficient for firm size is positive, but not significant.

As suggested above, an important issue in the simple OLS regressions is that each observation is accorded equal weight, whereas the reliability of the mean CARs varies quite considerably. Reliability depends on the sample size and variability in observed company CARs within the original study. Sample sizes differ greatly (between 4 and 561) and variability will differ across studies in different time periods and countries. An alternative measure that considers reliability is the $t$-statistic (or Z-statistic) derived from each study's mean CAR and its standard error. We use this measure as an alternative proxy for wealth effect using all sub-samples for which the measure can be derived; this

\footnotetext{
${ }^{15}$ Detailed results on the estimated numbers of unique and overlapping observations are available from the authors on request.
} 
restriction reduces the sample size somewhat to 60 (two-day) and 67 (all) observations. This analysis, which is included in Columns (4) to (6), provides a check that the CARbased results are not being biased by small-sample studies.

The results in Columns (4) to (6) are strongly in line with those in Columns (1) to (3). The coefficients for CB vs. WB, United States, and SSCI have the same sign and have comparable significance levels. The non-significant coefficients also remain nonsignificant. The only exception is the Refund variable. The sign for this variable is the same (negative). However, it is no longer significant and the $t$-statistics are very far from any significance level (between 0.12 and 0.27 ). This result probably means that the evidence on this variable presented in the first three columns must be viewed with some caution as it may be based on small sub-sample studies.

\section{Discussion of the results, conclusions, and future research directions}

This paper presents the results from a meta-analysis of 6,310 company announcements of convertible bonds and warrant-bonds, contained in 84 reported sub-samples from 35 studies. The result that stands out in this study is that hybrid debt announcements by US firms are associated with larger negative abnormal returns than those announced by companies in other countries, even market-oriented ones. ${ }^{16}$ A possible explanation for this result is that companies in the US are more widely held than those in other countries, where ownership is less dispersed. This difference may lead to US companies facing a larger information asymmetry between managers and investors compared to companies in other countries. This information asymmetry possibly translates itself in more negative abnormal returns. However, more analysis is needed to confirm whether the difference in abnormal returns is really driven by differences in information asymmetry.

A second interesting result is that we confirm evidence of a significant difference between abnormal returns associated with announcements of convertible bonds and of warrantbonds. Both univariate and multivariate analysis suggest that warrant-bonds show no

\footnotetext{
${ }^{16}$ The significant difference between US and Network-oriented countries is evident as the coefficient on US in the models presented within Table 3, as Network-oriented countries is the comparator (omitted) variable. Recasting the models with Non-US market as the comparator (omitted) variable enables a statistical test of the difference between US and non-US market. This shows that the latter difference is significant at the $10 \%$, 10\%, 5\% levels in the CAR-based Models (1), (2), and (3), respectively but in the t-stat-based Models (4) through (6) the difference is negative but not significant.
} 
significant negative wealth effect, on average, in direct contrast to the mean $-1.1 \%$ for convertibles. This result is consistent with theoretical expectations. A company issuing warrant-bonds has more flexibility than a company issuing convertible bonds. With a convertible bond, the bond disappears when the conversion right is exercised. This is not necessarily the case with a warrant-bond where it is possible to specify a different maturity for the bond and the warrants. Another potential advantage of warrant-bonds is that investors can separately trade the bonds and the warrants. This creates a benefit for the investor, while there is no obvious disadvantage to the issuing company. In light of this, it is perhaps surprising that, in recent years, warrant-bond issues seem to have virtually disappeared in practice.

Third, issuing hybrid securities to refund debt is not favoured by investors, which we speculate might result from a signalling effect. Failure to replace debt with further debt may suggest problems in banking relationships or perhaps even financial distress.

Finally, the lack of significant effects for several factors found to be important withinsample in prior research also suggests that more work is needed before we can claim to understand the wealth effects of hybrid securities. Such work might usefully encompass improvements in theory, in application of improved models (e.g. recognising and controlling for selection bias when comparing convertibles with warrant-bonds) and also in evidence from further study replications in different institutional environments.

What then should the research calendar for convertible bond and warrant-bond financing look like? First of all, the issue of the disappearance of warrant-bonds is a potentially interesting research topic. Why did companies stop issuing those? Second, more research on the relation between the security issuance and the purpose of the issue is needed. For example, De Jong, Dutordoir, and Verwijmeren (2011) study the simultaneous issue of convertible bonds and the repurchase of shares. It would be interesting to see what the market reactions to such a package are and how they relate to the results for the other purposes. ${ }^{17}$ Third, virtually all studies on convertible bonds that we analyse in this paper eliminate financial companies from their sample. The reason is that financial companies

\footnotetext{
${ }^{17}$ De Jong et al. (2011) study issuance day effects for these announcements and they find that the abnormal return for the combination $(0.32 \%)$ is significantly higher than for the separate issues of convertible bonds ($3.37 \%$ ). We are more interested in the announcement day effect. De Jong et al. (2011) state that the announcement and issuance dates coincide for more than $90 \%$ of their sample. However, to make results completely comparable, we would like to know the exact announcement effect.
} 
are different in terms of capital structure, because they tend to be more strongly levered. The only study that explicitly includes financial companies is the paper by Janjigian (1987). It is interesting to explicitly study convertible bond issues by financial companies and see if the announcement returns are different from those of industrial companies and utilities. Finally, our sample includes studies that were in the public domain on August 31, 2010 or before. More recently, a number of papers have studied the effect of convertible arbitrage by hedge funds. These funds buy newly-issued convertible bonds and at the same time short underlying shares. It is possible that this shorting of shares has a negative impact on the stock price, possibly already at the announcement date. It would be interesting to study this effect. For that purpose more recent samples than those summarized in this paper are necessary, because hedge fund involvement only increased from approximately the year 2000 (see, e.g. Brown, Lewis, Grundy, and Verwijmeren, 2012). A related topic is the influence of the recent financial crisis. During this period, the influence of hedge funds decreased. At the same time convertible bonds became popular with companies that had troubles attracting either straight debt or equity.

Even though a relatively large number of papers have studied announcements of convertible bond and warrant-bond issues, there seem to be enough topics left for an exciting research agenda. We look forward to seeing the results of these future studies. 


\section{References}

Abhyankar A. and Dunning, A., 1999. Wealth effects of convertible bond and convertible preference share issues: an empirical analysis of the UK market. Journal of Banking and Finance 23, pp.1043-1065.

Ammann, M., Fehr, M. and Seiz, R., 2006. New evidence on the announcement effect of convertible and exchangeable bonds. Journal of Multinational Financial Management 16, pp.43-63.

Armitage, S., 2010. Block buying and choice of issue method in UK seasoned equity offers. Journal of Business Finance and Accounting 37, pp.422-448.

Armitage, S. and Snell, A., 2001. Rights issues versus private placements: theory and UK evidence. Working Paper, University of Edinburgh.

Arshanapalli, B., Fabozzi, F., Switzer, L.N. and Gosselin, G., 2004. New evidence on the market impact of convertible bond issues in the U.S. Finance Letters 3, pp.1-6.

Arsiraphongphisit, O., 2008. The information conveyed by debt and equity announcements in Australia. International Journal of Banking and Finance 5, pp.61-86.

Asquith, P., 1995. Convertible bonds are not called late. The Journal of Finance 50, pp.1275-1289.

Balachandran, B., Faff, R. and Theobald, M., 2008. Rights offerings, takeup, renounceability, and underwriting status. Journal of Financial Economic 89, pp.328-346.

Barnes, E. and Walker, M., 2006. The seasoned-equity issues of UK firms: market reaction and issuance method choice. Journal of Business Finance and Accounting 33, pp.45-75.

Billingsley, R.S., Lamy, R.E. and Smith, D.M., 1990. Units of debt with warrants: evidence of the 'penalty free' issuance of an equity-like security. Journal of Financial Research 13, pp.187-199.

Brennan, M.J. and Her, C., 1995. Convertible bonds: test of financial signaling model. Working Paper, Anderson Graduate School of Management, University of California, Los Angeles.

Brown, S., Grundy, B., Lewis, C. and Verwijmeren, P., 2012. Convertibles and hedge funds as distributors of equity exposure. Review of Financial Studies (forthcoming).

Burlacu, R., 2000. New evidence on the pecking order hypothesis: the case of French convertible bonds. Journal of Multinational Financial Management 10, pp.439-459.

Chang, S-C., Chen, S-S. and Liu, Y., 2004. Why firms use convertibles: a further test of the sequential-financing hypothesis. Journal of Banking and Finance 28, pp.1163-1183. 
Cheng, W., Visaltanachoti N. and Kesayan P., 2005. A stock market reaction following convertible bond issuance: evidence from Japan. International Journal of Business 10, pp.323-339.

Christensen, D.G., Faria, H.J., Kwok, C.C.Y. and Bremer M., 1996. Does the Japanese stock market react differently to public security offering announcements than the US stock market. Japan and the World Economy 8, pp.99-119.

Dann, L.Y. and Mikkelson, W.H., 1984. Convertible debt issuance, capital structure change and financing-related information. Journal of Financial Economics 13, pp.157-186.

Datta, D.K., Pinches, G.E. and Narayanan, V.K., 1992. Factors influencing wealth creation from mergers and acquisitions: a meta-analysis. Strategic Management Journal 13, pp.6784.

Davidson III, W.N., Glascock, J.L. and Schwarz, T.V., 1995. Signaling with convertible debt. Journal of Financial and Quantitative Analysis 30, pp.425-440.

Day, B.H., 1999. A meta-analysis of wage-risk estimates of the value of a statistical life. CSERGE Working Papers, Centre for Social and Economic Research on the Global Environment (CSERGE), London, UK.

De Jong, A., Dutordoir, M. and Verwijmeren, P., 2011. Why do convertible bond issuers simultaneously repurchase stock? An arbitrage-based explanation. Journal of Financial Economics 100, pp.113-129.

De Roon, F. and Veld, C., 1998. Announcement effects of convertible bond loans: an empirical analysis for the Dutch market. Journal of Banking and Finance 22, pp.14811506.

Dutordoir M. and Van de Gucht, L., 2007. Are there windows of opportunity for convertible debt issuance? Evidence for Western Europe. Journal of Banking and Finance 31, pp.1-19.

Eckbo, B.E., 1986. Valuation effects of corporate debt offerings. Journal of Financial Economics 15, pp.119-151.

Eckbo, B.E. and Masulis, R.W., 1992. Adverse selection and the rights offer paradox. Journal of Financial Economics 32, pp.293-332.

Eckbo, B.E., Masulis, R.W., and Norli, O., 2007. Security offerings In: R. Hansen, J. Ritter, and X. Xu (Eds.), Handbook of Corporate Finance: Empirical Corporate Finance, North-Holland/Elsevier, pp.233-373.

Fenech, J.P., 2008. The stock market reaction to Australian convertible debt issues: new evidence. Investment Management and Financial Innovations 3, pp. 90-98.

Fields, L.P. and Mais, E.L., 1991. The valuation effect of private placements of convertible debt. The Journal of Finance 46, pp.1925-1932. 
Finnerty, J.D., 1986. The case of issuing synthetic convertible bonds. Midland Corporate Finance Journal 4, pp.73-82.

Gebhardt, G., 2001. Announcement effects of financing decisions by German companies: synthesis of an empirical research programme. Working Paper, Johann Wolfgang Goethe University Frankfurt (Germany).

Green, B.F. and Hall, J., 1984. Quantitative methods for literature reviews. Annual Review of Psychology 35, pp.37-54.

Hansen, R.S. and Crutchley, C., 1990. Corporate earnings and empirical analysis. Journal of Business 63, pp.347-371.

Heckman, J.T., 1979. Sample bias as a specification error. Econometrica 47, pp.153-161.

Janjigian, V., 1987. The leverage changing consequences of convertible debt financing. Financial Management 16, pp.15-21.

Jayamaran, N., Shastri, K. and Tandon, K., 1990. Valuation effects of warrants in new security issues. Working Paper, Salomon Center, New York University.

Jen, F.C., Choi, D. and Lee, S-H., 1997. Some new evidence on why companies use convertible bonds. Journal of Applied Corporate Finance 10, pp.44-53.

Jones, E.P. and Mason, S.P., 1986. Equity-linked debt. Midland Corporate Finance Journal 3, pp.47-58.

Kang, J.-K, Kim Y.-C., Park J. and Stulz, R.M., 1995. An analysis of the wealth effects of Japanese offshore dollar-denominated convertible and warrant bond issues. Journal of Financial and Quantitative Analysis 30, pp.257-270.

Kang, J.-K. and Stulz, R.M., 1996. How different is Japanese corporate finance? An investigation of the information content of new security issues. Review of Financial Studies 9, pp.109-139.

Kothare, M., 1997. The effects of equity issues on ownership structure and stock liquidity: a comparison of rights and public offerings. Journal of Financial Economics 43, pp.131148.

La Porta, R., Lopez-de-Silanes, F., Shleifer, A. and Vishny, R.W., 2000. Agency problems and dividend policies around the world. The Journal of Finance 55, pp.1-33.

Lewis, C.M., Rogalski, R.J. and Seward, J.K., 2003. Industry conditions, growth opportunities and market reactions to convertible debt financing decisions. Journal of Banking and Finance 27, pp.153-181.

Li, X.-J and Wang, P.-X., 2008. Market reaction on convertible bonds offering: an agency cost of free cash flow perspective. China-USA Business Review 7, pp.7-12. 
Loncarski, I., Ter Horst, J. and Veld, C., 2006. Why do companies issue convertible bonds? A review of theory and empirical evidence. In: L. Renneboog (ed.), Advances in Corporate Finance and Asset Pricing, Elsevier, Amsterdam, pp.311-339.

Loncarski, I., Ter Horst, J. and Veld, C., 2008. Why do companies issue convertible bond loans? An empirical analysis for the Canadian market. Canadian Journal of Administrative Sciences 25, pp.214-236.

Long, M.S. and Sefcik, S.E., 1990. Participation financing: A comparison of the characteristics of convertible debt and straight bonds issued in conjunction with warrant. Financial Management 19, pp.23-34.

Marquardt, C. and Wiedman, C., 2005. Earnings management through transaction structuring: contingent convertible debt and diluted earnings per share. Journal of Accounting Research 43, pp.205-243.

Masters, B., 2009. Companies return to convertibles. Financial Times, May 11.

Mayers, D., 1998. Why firms issue convertible bonds: the matching of financial and real investment options. Journal of Financial Economics 47, pp.83-102.

Mikkelson, W.H. and Partch, M.M., 1986. Valuation effects of security offerings and the issuance process. Journal of Financial Economics 15, pp.31-60.

Moerland, P.W., 1995. Alternative disciplinary mechanisms in different corporate systems. Journal of Economic Behavior and Organization 26, pp.17-34.

Mohd Ashhari, Z. and Sin-Chun, L., 2009. The effect of debt announcements: straight bond vs convertible bond. In: Universiti Teknologi Petronas, Regional Conference on the Humanities. Perak, Malaysia.

Mollemans, M., 2002. The announcement effect in Japan. Working Paper, Macquarie University.

Myers, S.C. and Majluf, N., 1984. Corporate financing and investment decisions when firms have information that investors do not have. Journal of Financial Economics 13, pp.187-221.

Nelson, J.P and Kennedy, P.E., 2009. The use (and abuse) of meta-analysis in environmental and natural resource economics: an assessment. Environmental and Resource Economics 42, pp.345-377.

Phelps, K.L., Moore, W.T. and Roenfeldt R.L., 1991. Equity valuation effects of warrantdebt financing. Journal of Financial Research 14, pp.93-103.

Ross, S., 1977. The determinants of capital structure: The incentive signalling approach. Bell Journal of Economics 8, pp.23-40.

Slovin, M.B., Sushka, M.E. and Lai, K.W.L., 2000. Alternative flotation methods, adverse selection and ownership structure: evidence from seasoned equity issuance in the U.K. Journal of Financial Economics 57, pp.157-190. 
Smith, C.W., 1986. Investment banking and the capital acquisition process. Journal of Financial Economics 15, pp.3-29.

Stein, J.C., 1992. Convertible bonds as backdoor equity financing. Journal of Financial Economics 32, pp.3-21.

Suchard, J.A., 2007. The impact of right issued of convertible debt in Australian markets. Journal of Multinational Financial Management 17, pp.187-202.

Veld, C. and Veld-Merkoulova, Y., 2009. Value creation through spin-offs: a review of empirical evidence. International Journal of Management Reviews 11, pp.407-420.

Wolf, F.M., 1986. Meta-analysis: quantitative methods for research synthesis. Sage University Paper series on Quantitative Applications in the Social Sciences, 07-059. Beverly Hills: Sage Pubns. 
Table 1: Studies of the market reaction to announcements of convertible bonds and warrant-bonds

\begin{tabular}{|c|c|c|c|c|c|c|c|}
\hline \multirow[b]{2}{*}{ Study } & \multirow[b]{2}{*}{ Country } & \multirow[b]{2}{*}{$\begin{array}{c}\text { Research } \\
\text { Period }\end{array}$} & \multirow[b]{2}{*}{$\begin{array}{c}\text { Event } \\
\text { Window }\end{array}$} & \multicolumn{2}{|c|}{ Number of observations } & \multicolumn{2}{|c|}{$\begin{array}{c}\text { Cumulative abnormal } \\
\text { return }(\%)\end{array}$} \\
\hline & & & & $\begin{array}{c}\text { Convertible } \\
\text { Bonds }\end{array}$ & $\begin{array}{c}\text { Warrant } \\
\text { Bonds }\end{array}$ & $\begin{array}{c}\text { Convertible } \\
\text { Bonds }\end{array}$ & $\begin{array}{c}\text { Warrant } \\
\text { Bonds }\end{array}$ \\
\hline \multicolumn{8}{|l|}{ Market-oriented country studies } \\
\hline Dann and Mikkelson (1984) & United States & 1970-1979 & $(-1,0)$ & 132 & & $-2.31 * * *$ & \\
\hline Eckbo (1986) & United States & 1964-1981 & $(-1,0)$ & 75 & & $-1.25 * * *$ & \\
\hline Mikkelson and Partch (1986) & United States & 1972-1982 & $(-1,0)$ & 33 & & $-1.97 * * *$ & \\
\hline Janjigian (1987) & United States & $1968-1983$ & $(-1,0)$ & 301 & & $-1.71 * * *$ & \\
\hline Billingsley, Lamy, and Smith (1990) & United States & 1971-1986 & $(-1,0)$ & 104 & 38 & $-2.04 * * *$ & -0.33 \\
\hline Hansen and Crutchley (1990) & United States & 1975-1982 & $(-1,0)$ & 67 & & $-1.45 * * *$ & \\
\hline Long and Sefcik (1990) & United States & 1965-1984 & $(-1,0)$ & 134 & 54 & $-0.61 * * *$ & $-1.59 * * *$ \\
\hline Jayamaran, Shastri, and Tandon (1990) & United States & $1977-1986$ & $(-1,0)$ & & 54 & & -0.64 \\
\hline Fields and Mais (1991) & United States & 1970-1987 & $(-1,0)$ & 61 & & $1.80 * *$ & \\
\hline Phelps, Moore, and Roenfeldt (1991) & United States & 1970-1986 & $(-1,0)$ & & 39 & & $-1.32 * *$ \\
\hline Brennan and Her (1995) & United States & $1976-1985$ & $(-1,0)$ & 155 & & $-2.20 * * *$ & \\
\hline Asquith (1995) & United States & 1980-1982 & 0 & 183 & & $-1.03 * * *$ & \\
\hline Davidson, Glascock, and Schwarz (1995) & United States & $1980-1985$ & $(-1,0)$ & 118 & & $-1.40 * * *$ & \\
\hline Jen, Choi, and Lee (1997) & United States & 1976-1985 & $(-1,0)$ & 158 & & $-2.15^{* * *}$ & \\
\hline Lewis, Rogalski, and Seward (2003) & United States & 1978-1992 & $(-1,0)$ & 588 & & $-1.09^{n}$ & \\
\hline Arshanapalli et al. (2004) & United States & 1993-2001 & $(-1,0)$ & 85 & & $-3.07 * * *$ & \\
\hline Marquardt and Wiedman (2005) & United States & 2000-2002 & $(-1,0)$ & 207 & & $-5.50 * * *$ & \\
\hline Abhyankar and Dunning (1999) & United Kingdom & 1986-1996 & $(0,1)$ & 112 & & $-1.21 * * *$ & \\
\hline Loncarski, Ter Horst, and Veld (2008) & Canada & 1991-2004 & $(-1,0)$ & 86 & & $-0.54 *$ & \\
\hline Suchard (2007) & Australia & 1980-2002 & $(0,1)$ & 58 & & -0.40 & \\
\hline Fenech (2008) & Australia & 1999-2007 & $(-1,0)$ & 126 & & 0.69 & \\
\hline Arsiraphongphisit (2008) & Australia & 1991-2003 & $(-1,0)$ & 43 & & $-0.61 * *$ & \\
\hline
\end{tabular}




\begin{tabular}{|c|c|c|c|c|c|c|c|}
\hline \multirow[b]{2}{*}{ Study } & \multirow[b]{2}{*}{ Country } & \multirow[b]{2}{*}{$\begin{array}{c}\text { Research } \\
\text { Period }\end{array}$} & \multirow[b]{2}{*}{$\begin{array}{c}\text { Event } \\
\text { Window }\end{array}$} & \multicolumn{2}{|c|}{$\begin{array}{c}\text { Number of } \\
\text { observations }\end{array}$} & \multicolumn{2}{|c|}{$\begin{array}{c}\text { Cumulative abnormal } \\
\text { return }(\%)\end{array}$} \\
\hline & & & & $\begin{array}{c}\text { Convertible } \\
\text { Bonds }\end{array}$ & $\begin{array}{c}\text { Warrant } \\
\text { Bonds }\end{array}$ & $\begin{array}{c}\text { Convertible } \\
\text { Bonds }\end{array}$ & $\begin{array}{c}\text { Warrant } \\
\text { Bonds }\end{array}$ \\
\hline \multicolumn{8}{|l|}{ Network-oriented country studies } \\
\hline Kang et al. (1995) & Japan & 1977-1989 & $(-1,0)$ & 83 & 368 & -0.22 & $0.61 * *$ \\
\hline Christensen et al. (1996) & Japan & 1984-1991 & $(-1,0)$ & 35 & 32 & 0.60 & -0.67 \\
\hline Kang and Stulz (1996) & Japan & 1985-1991 & $(-1,0)$ & 561 & 19 & $0.83^{* * *}$ & -0.21 \\
\hline Mollemans (2002) & Japan & $1992-2002$ & $(0,1)$ & 367 & & $-1.01 * * *$ & \\
\hline Cheng, Visaltanachoti, and Kesayan (2005) & Japan & 1996-2002 & $(0,1)$ & 172 & & $-0.92 * * *$ & \\
\hline De Roon and Veld (1998) & The Netherlands & 1976-1996 & $(-1,0)$ & 47 & 19 & 0.16 & 0.75 \\
\hline Burlacu (2000) & France & 1981-1998 & $(-1,0)$ & 141 & & $-0.40 * * *$ & \\
\hline Gebhardt (2001) & Germany & 1980-1994 & $(-2,1)$ & & 69 & & $1.20 * *$ \\
\hline Chang, Chen, and Liu (2004) & Taiwan & 1990-1999 & $(-1,0)$ & 109 & & 0.42 & \\
\hline Ammann, Fehr and Seiz (2006) & Switzerland and Germany & 1996-2003 & $(0,1)$ & 55 & & $-1.36^{* *}$ & \\
\hline Dutordoir and Van de Gucht (2007) & Western Europe & 1990-2002 & $(-1,0)$ & 188 & & $-1.35 * * *$ & \\
\hline Li and Wang (2008) & China & $2001-2005$ & $(-1,0)$ & 48 & & $-1.34 * * *$ & \\
\hline Mohd Ashhari and Sin-Chun (2009) & Malaysia & 1994-2003 & $(-1,0)$ & 29 & & $-1.51 * *$ & \\
\hline
\end{tabular}

*** significant at the $1 \%$-level, ${ }^{* *}$ significant at the $5 \%$-level, $*$ significant at the $10 \%$-level, ${ }^{\mathrm{n}}$ the authors do not present the significance level 
Table 2: Cumulative abnormal returns around announcements of convertible bonds and warrant-bonds

\begin{tabular}{|l|c|c|}
\hline \multirow{2}{*}{} & \multicolumn{2}{|c|}{ CAR\% } \\
\cline { 2 - 3 } & Convertibles & Warrant-bonds \\
\hline Mean & $-1.14 * * *$ & -0.02 \\
\hline Medat $)$ & $(-6.07)$ & $(-0.07)$ \\
\hline Standard deviation & -1.02 & -0.27 \\
\hline Minimum & 1.62 & 1.09 \\
\hline Maximum & -8.27 & -1.59 \\
\hline Number of studies & 2.37 & 1.41 \\
\hline Number of companies within studies & 74 & 10 \\
\hline
\end{tabular}

*** mean CAR\% is significantly different from 0 at the $1 \%$-level (t-test; 2 -tail)

A two-sample t-test confirms that the mean CAR\% for convertibles is significantly lower (more negative) than for warrant-bonds, at the 5\%-level $(t=2.11)$. The equivalent nonparametric test (Wilcoxon rank-sum/Mann-Whitney) confirms that the distributions differ at the $5 \%$-level $(Z=2.31 ; p=0.02)$ 
Table 3: Meta analysis results

\begin{tabular}{|c|c|c|c|c|c|c|c|}
\hline \multicolumn{2}{|l|}{ Dependent variable } & \multicolumn{3}{|c|}{ mean Cumulative Abnormal Returns } & \multicolumn{3}{|c|}{$t$-statistic } \\
\hline Independent variables & $\begin{array}{l}\text { Exp } \\
\text { Sign }\end{array}$ & $\begin{array}{c}2 \text { day } \\
\text { window } \\
(1)\end{array}$ & $\begin{array}{c}2 \text { day } \\
\text { window } \\
(2) \\
\end{array}$ & $\begin{array}{c}\text { all } \\
\text { studies } \\
(3) \\
\end{array}$ & $\begin{array}{c}2 \text { day } \\
\text { window } \\
(4) \\
\end{array}$ & $\begin{array}{c}2 \text { day } \\
\text { window } \\
(5) \\
\end{array}$ & $\begin{array}{c}\text { all } \\
\text { studies } \\
(6) \\
\end{array}$ \\
\hline CB vs. WB & - & $\begin{array}{c}-0.67 * * \\
(-2.41)\end{array}$ & $\begin{array}{c}-0.64 * * \\
(-2.03)\end{array}$ & $\begin{array}{c}-0.77 * * \\
(-2.51)\end{array}$ & $\begin{array}{c}-2.51 * * \\
(-2.46)\end{array}$ & $\begin{array}{c}-3.02 * * \\
(-2.43)\end{array}$ & $\begin{array}{l}-1.87 * \\
(-1.83)\end{array}$ \\
\hline Mixed-like & $?$ & $\begin{array}{c}-0.15 \\
(-0.61)\end{array}$ & $\begin{array}{c}-0.19 \\
(-0.80)\end{array}$ & $\begin{array}{c}-0.14 \\
(-0.53)\end{array}$ & $\begin{array}{l}-2.72 \\
(-1.00)\end{array}$ & $\begin{array}{c}-2.56 \\
(-0.68)\end{array}$ & $\begin{array}{c}-2.62 \\
(-0.90)\end{array}$ \\
\hline Equity-like & - & $\begin{array}{c}-0.12 \\
(-0.58)\end{array}$ & $\begin{array}{c}-0.16 \\
(-0.58)\end{array}$ & $\begin{array}{c}-0.12 \\
(-0.57)\end{array}$ & $\begin{array}{l}-2.68 \\
(-0.75)\end{array}$ & $\begin{array}{l}-2.68 \\
(-0.62)\end{array}$ & $\begin{array}{c}-2.68 \\
(-0.70)\end{array}$ \\
\hline Non-US Market & - & $\begin{array}{c}-0.08 \\
(-0.16)\end{array}$ & $\begin{array}{c}-0.08 \\
(-0.14)\end{array}$ & $\begin{array}{c}-0.31 \\
(-0.62)\end{array}$ & $\begin{array}{l}-1.05 \\
(-0.81)\end{array}$ & $\begin{array}{c}-1.64 \\
(-0.93)\end{array}$ & $\begin{array}{c}-1.45 \\
(-1.08)\end{array}$ \\
\hline United States & - & $\begin{array}{c}-1.11 * * * \\
(-3.98)\end{array}$ & $\begin{array}{c}-1.13 * * * * \\
(-3.38)\end{array}$ & $\begin{array}{c}-1.54 * * * \\
(-4.99)\end{array}$ & $\begin{array}{c}-2.26 * * * \\
(-2.69)\end{array}$ & $\begin{array}{c}-3.43 * * * \\
(-3.72)\end{array}$ & $\begin{array}{c}-3.03 * * * \\
(-3.66)\end{array}$ \\
\hline Rights & $?$ & $\begin{array}{c}0.36 \\
(0.90)\end{array}$ & $\begin{array}{c}0.11 \\
(0.24)\end{array}$ & $\begin{array}{c}0.53 \\
(1.45)\end{array}$ & $\begin{array}{c}0.97 \\
(0.61)\end{array}$ & $\begin{array}{c}0.47 \\
(0.20)\end{array}$ & $\begin{array}{c}0.71 \\
(0.42)\end{array}$ \\
\hline Refund & - & $\begin{array}{c}-1.62 * * \\
(-2.35)\end{array}$ & $\begin{array}{c}-2.04 * * * \\
(-2.97)\end{array}$ & $\begin{array}{c}-1.63 * * \\
(-2.36)\end{array}$ & $\begin{array}{l}-0.19 \\
(-0.12)\end{array}$ & $\begin{array}{l}-0.49 \\
(-0.17)\end{array}$ & $\begin{array}{c}-0.45 \\
(-0.27)\end{array}$ \\
\hline Capital Expenditure & $?$ & $\begin{array}{c}-0.03 \\
(-0.04)\end{array}$ & $\begin{array}{c}0.16 \\
(0.21)\end{array}$ & $\begin{array}{c}-0.03 \\
(-0.05)\end{array}$ & $\begin{array}{c}1.62 \\
(1.02)\end{array}$ & $\begin{array}{c}2.09 \\
(0.69)\end{array}$ & $\begin{array}{c}1.36 \\
(0.80)\end{array}$ \\
\hline Rating (Higher) & - & $\begin{array}{c}-0.21 \\
(-0.28)\end{array}$ & $\begin{array}{c}-0.50 \\
(-0.91)\end{array}$ & $\begin{array}{c}0.02 \\
(0.03)\end{array}$ & $\begin{array}{c}1.56 \\
(1.11)\end{array}$ & $\begin{array}{c}1.89 \\
(0.64)\end{array}$ & $\begin{array}{c}1.59 \\
(1.18)\end{array}$ \\
\hline Size (Larger) & + & & & $\begin{array}{c}0.21 \\
(0.58)\end{array}$ & & & $\begin{array}{c}0.74 \\
(0.43)\end{array}$ \\
\hline Industrial & - & $\begin{array}{c}-0.37 \\
(-1.16)\end{array}$ & $\begin{array}{c}-0.25 \\
(-0.67)\end{array}$ & $\begin{array}{l}-0.20 \\
(-0.65)\end{array}$ & $\begin{array}{c}-0.34 \\
(-0.41)\end{array}$ & $\begin{array}{l}-0.06 \\
(-0.06)\end{array}$ & $\begin{array}{c}0.27 \\
(0.32)\end{array}$ \\
\hline SSCI & $?$ & $\begin{array}{c}0.51 * * \\
(2.02)\end{array}$ & $\begin{array}{c}0.66 * * \\
(2.24)\end{array}$ & $\begin{array}{c}0.73 * * \\
(2.62)\end{array}$ & $\begin{array}{c}1.85 * * \\
(2.31)\end{array}$ & $\begin{array}{c}2.68 * * * \\
(2.72)\end{array}$ & $\begin{array}{l}1.87 * * \\
(2.25)\end{array}$ \\
\hline Intercept & & $\begin{array}{c}0.19 \\
(0.51)\end{array}$ & $\begin{array}{c}0.17 \\
(0.44)\end{array}$ & $\begin{array}{c}0.32 \\
(0.84)\end{array}$ & $\begin{array}{c}2.63 \\
(0.87)\end{array}$ & $\begin{array}{c}2.92 \\
(0.72)\end{array}$ & $\begin{array}{c}2.38 \\
(0.75)\end{array}$ \\
\hline Robust standard errors & & yes & yes & yes & no & no & no \\
\hline Adjusted $\mathbf{R}^{2}$ & & $30.4 \%$ & $32.3 \%$ & $36.7 \%$ & $19.4 \%$ & $30.2 \%$ & $25.1 \%$ \\
\hline $\mathbf{F}$ & & $6.97 * * *$ & $9.39 * * *$ & $8.17 * * *$ & $2.29 * *$ & $3.32 * * *$ & $2.85 * * *$ \\
\hline No. of observations & & 75 & 75 & 83 & 60 & 60 & 67 \\
\hline
\end{tabular}

Notes: Models (1) and (4) are unweighted OLS regressions based on studies reporting 2 day event window mean CARs and $t$ statistics, respectively. Models (2) and (5) are Weighted Least Squares regressions based on 2 day event window mean CARs and $t$-statistics, respectively. The weights are square-root (adjusted sample size), where each observation sample size is adjusted to reflect overlapping observations within countries and also within a single research study. Models (3) and (6) are unweighted OLS regressions based on all studies mean CARs and $t$-statistics, respectively.

The independent variables are: CB vs. WB (= 1 for convertibles; $=0$ for warrant-bonds), Mixed-like ( $=1$ for convertibles that are not identified as equity-like or debt-like in the original paper), Equity-like ( $=1$ for convertibles that are defined as equitylike in the original paper), the omitted dummy is for Debt-like convertibles; Non-US Market (studies based on data from UK, Canada and Australia), United States (studies based on US data), the omitted variable is network-oriented countries (studies using data from all other countries); Rights (= 1 if rights issue), Refund (= 1 if hybrid used to refund debt), Capital expenditure ( $=1$ if hybrid used to finance capital expenditure), Rating (=1 for higher Moody's rating), Size (= 1 for companies that are in the top half of large companies in the original paper), Industrial, and SSCI (= 1 if study published in the Social Science Citation Index journal list for 2008).

Table reports coefficients (with $t$-statistics in parentheses). The Breusch-Pagan/Cook-Weisberg test indicates heteroskedasticity in the CAR-based models (1), (2) and (3) but not for models (4), (5) and (6) so Huber-White adjusted $t$ statistics are used for models (1), (2) and (3) only.

$* * *$ significant at the $1 \%$-level, ** significant at the $5 \%$-level, * significant at the $10 \%$-level (2-tail tests). 